\title{
$\mathrm{MMT}$ 첨가에 따른 Polyamide/MMT 나노복합체의 흡습 특성
}

\author{
박상철 · 김호겸 · 민경은 \\ 경북대학교 고분자공학과 \\ (2012년 9월 14일 접수, 2012년 10월 18일 수정, 2012년 10월 22일 채택)
}

\section{Effect of MMT on Anti-Water Absorption of Polyamide/MMT Nanocomposites}

\author{
Sang-Cheol Park, Ho-Gyum Kim, and Kyung-Eun Min ${ }^{\dagger}$ \\ Department of Polymer Science, Kyungpook National University, Daegu 702-701, Korea \\ (Received September 14, 2012; Revised October 18, 2012; Accepted October 22, 2012)
}

초록: Pilot scale에서의 나노복합체의 상용화를 위해 용융 삽입법을 적용하고 이축 압출기로 제조한 polyamide/MMT 나노복합체의 흡습 특성을 연구한 결과, MMT 도입으로 수분 흡수율이 감소되었으며 그에 따라 치수 안정성이 향 상되었다. 굴곡강도 및 탄성률은 수분 흡수율이 증가함에 따라 저하되었으며, 이로부터 $\mathrm{MMT}$ 의 도입은 강도 향상 효과와 함께 흡습방지를 통한 강도 저하 억제효과도 보이는 것으로 조사되었다.

\begin{abstract}
The melt intercalation to commercialize nanocomposites in a pilot scale was applied and the water absorption characteristics for polyamide/MMT nanocomposites manufactured by twin screw extruder was studied. As a result, water absorption decreased with the introduction of MMT and dimensional stability was improved. However, as water absorption increased, flexural strength and modulus were reduced. Therefore, the effect of MMT introduction on mechanical properties of nanocomposites was clearly observed, which may increase the level of strength by maintaining anti-water absorption property of nanocomposite.
\end{abstract}

Keywords: polyamide, nanocomposite, water absorption, dimensional stability, flexural.

\begin{abstract}
서 론
폴리아미드계 고분자는 일반적으로 결정성이 높고 기계적 강도, 열안정성, 내마모성 등이 우수하여 다양한 분야에서 여 러 가지 용도로 적용되고 있으며, 폴리아미드 및 MMT(montmorillonite)의 나노복합체(nanocomposite)의 기계적 성질, 열 안정성 등에 대해서도 많은 연구가 이루어져 왔다. ${ }^{1-18}$ 나노복 합체의 기계적 및 열적 성질이 부품 요구규격을 만족하는 경 우라도 부품의 특성 및 용도에 따라 사용되는 환경에 대한 특성인 내환경성에 대한 정보가 요구되며, 특히 대기 환경에 노출된 상태에서 저장 및 사용되어지는 제품의 경우 대기 중 의 수분에 의한 흡습 특성 연구가 요구된다. 탄약과 같은 특 수한 용도로의 적용을 위해서는 더욱 그러하다 할 수 있다. 근래 탄약 부품 재료로서 기능 및 장기 저장성 향상, 원가절 감, 가공성 향상 등을 위해 기존의 금속(metal) 재료를 고분 자 복합체로 대체하려는 시도가 진행되고 ${ }^{19}$ 있으므로 나노복 합체의 상용화 적용 검토를 위해서는 흡습에 따른 내환경성
\end{abstract}

To whom correspondence should be addressed.

E-mail: minkye@knu.ac.kr
에 대한 연구가 반드시 요구된다.

폴리아미드는 다른 고분자에 비해 재료특성이 탄약 부품으 로서의 요구 성능에 부합하여 과거부터 적용되는 사례가 많 다. 그러나 일부 탄약 부품에 있어서는 흡습에 따른 치수변 동으로 인해 탄약 운용상의 문제를 발생시킬 가능성이 내재 되어 있다. 이러한 현상은 폴리아미드계 고분자의 흡습 특성 에서 기인한 것으로 사슬 내에 친수성이 강한 amide group이 존재하기 때문이다. 즉, amide-amide 수소결합이 amide-water 수소결합으로 치환됨에 따른 현상으로 전체 amide group의 농도에 많은 영향을 받는다. 흡습된 수분은 가소제와 같은 역 할을 하여 기계적 성질에도 영향을 미치며, 제품 치수 변화 의 요인으로 작용하게 된다. ${ }^{719-21}$ 탄약 부품과 같이 치수 정 밀성이 요구되면서 일반 대기 중에 장기보관이 이루어지는 용도로의 재료는 흡습에 따른 치수변화가 최소화 되어야 한 다. 이러한 흡습성에 대한 방지 조치로써 유리섬유 등의 충 전제를 적용할 수도 있으나, 비중의 증가에 따른 탄약 중량 변동, 무게중심 및 비행 탄도의 변화 등이 동반되므로 적용 상에 한계가 있다고 할 수 있다. ${ }^{21}$ 반면, MMT를 적용한 나 노복합체는 이러한 비중의 변동을 최소화하면서도 흡습 방지 및 그에 따른 치수 안정성의 확보가 가능한 것으로 알려져 
있으므로 나노복합체는 금속 재료를 고분자로 대체함에 있어 큰 장점을 지닌다고 할 수 있다. ${ }^{7.21}$ 따라서 탄약 부품과 같이 특수한 용도가 요구되는 부품에 나노복합체를 적용하기 위해 서는 흡습성, 흡습에 따른 치수변화, 흡습에 따른 기계적 성 질 변화 등과 같은 흡습 특성에 대한 연구결과의 확보가 요 구된다. 현재까지 나노복합체의 흡습 특성에 대한 연구는 Nylon 6에 대해 일부 보고되어져 있으나 극히 소수에 불과하 며, ${ }^{22}$ 흡습시의 기계적 성질에 대해서는 인장응력에 대한 연 구결과만이 일부 보고되어 있을 뿐, ${ }^{23}$ Nylon 66 나노복합체 에 대한 흡습 특성 및 흡습시의 굴곡강도 및 충격강도에 대 한 연구는 찾아보기 힘든 실정이다. ${ }^{21,24}$

본 연구에서는 폴리아미드/MMT 나노복합체의 특성을 연 구함에 있어 나노복합체의 상용화와 탄약 부품과 같이 특수 한 용도로의 적용을 위해 흡습 특성을 비롯한 굴곡 및 충격 응력에 대한 강도 영향을 알아보고자 하였다. 본 연구에 적 용된 폴리아미드는 앞서 본 연구실의 폴리아미드 나노복합체 연구에서 저점도, 즉 분자량이 낮은 경우 결정화 거동의 영 향에 의해 수분 흡습 환경에서 유리할 것으로 판단하여 상대 적으로 저점도인 Nylon 66(Rhodia사의 Technyl A205F)을 선 정했으며, MMT로는 유기화 처리된 상용 MMT인 Southern Clay사의 Cloisite $93 \mathrm{~A}$ 를 적용하였다. 나노복합체 제조 방법 으로는 MMT의 분산성을 확보함과 동시에 경제성, 친환경성 등의 장점으로 상용화가 용이한 것으로 알려진 용융 삽입법 (melt intercalation)을 적용하였다. 724,25 이는 본 연구실의 나노 복합체에 대한 앞선 연구에서 Figure 1에 나타낸 것과 같이 MMT의 충분한 분산을 확인한 제조방법이다.

\section{실 험}

재료 및 제조. Nylon 66는 Rhodia사의 Technyl A205F를 사용하였으며, 용융 흐름 지수(melt flow index)를 ASTM D1238(melt flow rates of thermoplastics by extrusion plastometer)에 따라 온도 $275^{\circ} \mathrm{C}, 1.2 \mathrm{~kg}$ 하중에서 melt index tester(extrusion plastometer, TOYOSEIKI)로 측정한 결과, $57.4 \mathrm{~g} / 10 \mathrm{~min}$ 이었다. MMT는 유기화 처리한 Southern Clay 사의 Cloisite 93A(M2HT, $90 \mathrm{meq} / 100 \mathrm{~g})$ 를 1 10 phr 범 위로 적용하였다. 1 차 산화방지제는 라디칼 연쇄 개시반응 금지제 로서 Ciba specialty chemicals사의 IRGANOX 1010 을 $0.2 \mathrm{phr}$ 로 적용하였으며, 2차 산화방지제는 과산화물 분해제로서 Ciba specialty chemicals사의 IRGAFOS 168 을 $0.2 \mathrm{phr}$ 로 적용 하였다. 활제로는 고융점 합성왁스인 (주)신원화학의 Ethylene Bis Stearamide(HI-LUBE ${ }^{\mathrm{TM}}$ )를 $0.2 \mathrm{phr}$ 로 적용하였다.

나노복합체 제조방법으로는 이축 압출기(twin screw extruder)에 의한 용융 삽입법을 적용하였는데, polyamide/유 리섬유 복합체 등 현재의 상용 고분자 복합체 제조에 적용 중인 pilot scale 생산설비이다. 혼합공정은 현재 상용 복합체

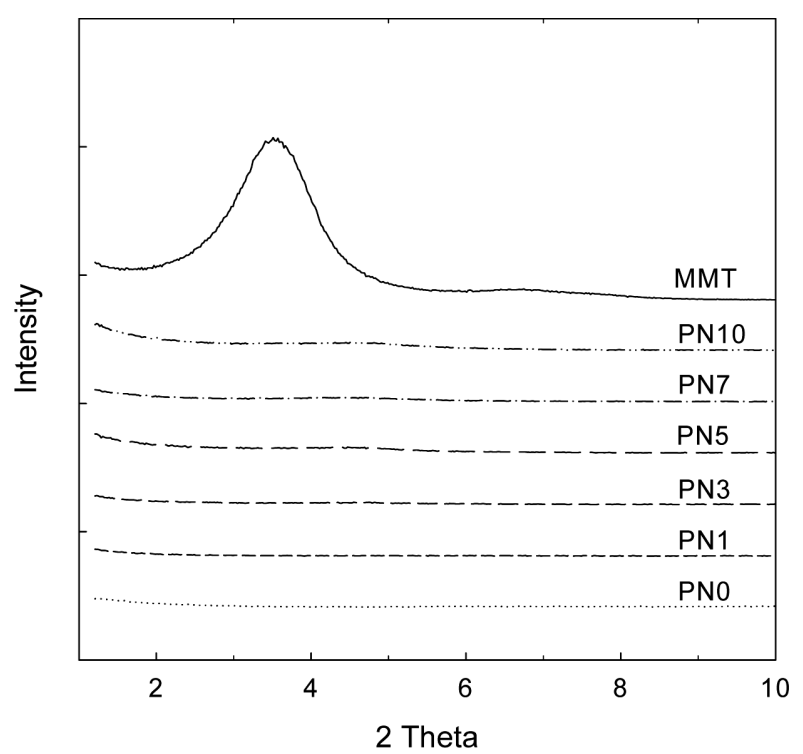

Figure 1. X-ray diffraction patterns of MMT and nanocomposite with various mixing conditions.

의 제조에 적용중인 기계식 교반형 혼합 장비(super mixer; SHINHWA)를 적용하였다. 혼합 장비에 Nylon $6610 \mathrm{~kg}$ 에 MMT를 일정량 $(1,3,5,7,10 \mathrm{phr})$ 투입하고, 산화방지제 및 활제를 동시 투입하여 $800 \mathrm{rpm}$ 으로 2 분 동안 혼합하였다. 혼 합 전, Nylon 66 은 진공 건조기에서 약 $120^{\circ} \mathrm{C}$ 로 8 시간, $\mathrm{MMT}$ 는 약 $100^{\circ} \mathrm{C}$ 에서 8 시간 건조 후 사용하였다. 혼합 완 료 후 이축 압출기인 TEK-45(SM Engineering)을 이용하여 온도 $280{ }^{\circ} \mathrm{C}$ 에서 screw 회전수 $200 \mathrm{rpm}$ 으로 압출하였다. 압 출된 나노복합체는 시편 사출기 IDE $75 \mathrm{EN}$ 을 이용하여 nozzle 온도 $285^{\circ} \mathrm{C}$ 에서 온도 $60^{\circ} \mathrm{C}$ 시편 금형에 동일한 조건으로 사 출 후 상온 $\left(\right.$ 약 $\left.25^{\circ} \mathrm{C}\right)$ 에서 자연 냉각하여 시편을 제작하였다. 본 연구의 시편을 구분하기 위한 시료 번호(sample code)는 $\mathrm{PN}$ 으로 표시하고, 그 뒤에 MMT 도입 함량을 표시하였다. 즉, MMT 함량 $1,3,5,7,10 \mathrm{phr}$ 가 도입된 시료에 대해 각 각 $\mathrm{PN} 1, \mathrm{PN} 3, \mathrm{PN} 5, \mathrm{PN} 7, \mathrm{PN} 10$ 으로 나타내고, $\mathrm{PN} 0$ 는 $\mathrm{MMT}$ 가 도입되지 않은 시료를 나타내었다.

흡습 특성. 수분 흡수율(water absorption) 시험방법은 미국 military specification(MIL-P-63510)에서 제시한 방법을 적용 하였으며, 시편은 폭 $12.75 \mathrm{~mm}$, 두께 $6.4 \mathrm{~mm}$, 길이 $126.7 \mathrm{~mm}$ 의 직육면체 형상을 사용하였다. 측정방법은 시편을 건조기 에서 $71 \pm 1{ }^{\circ} \mathrm{C}$ 에서 24 시간 건조한 후 냉각시켜 중량을 측정하 고, 다시 $71 \pm 1{ }^{\circ} \mathrm{C}$ 에서 8 시간 건조한 후 냉각시켜 중량을 측 정하였다. 이러한 과정을 반복하여 연속되는 두 개의 측정치 의 차가 $5 \mathrm{mg}$ 이하일 때 값을 건조중량(conditioned weight, $\mathrm{CW}$ )으로 측정하였다. 건조중량 측정 후, 시편을 $23 \pm 1{ }^{\circ} \mathrm{C}$ 증 류수에서 24시간 동안 침지한 후 가습중량(wet weight, WW) 을 측정하였다. 건조중량과 가습중량을 이용하여 24시간 수 
분 흡수율(24hr-Water absorption)을 식 (1)로 계산하였다.

$$
\frac{(W W-C W)}{C W} \times 100=24 \mathrm{hr}-\text { Water absorption(\%) }
$$

동일한 시험방법으로 수분 흡수 시험을 약 900 시간 동안 진행하여 침지시간에 따른 수분 흡수율을 확인하였으며, 그 결과로부터 수분 확산계수(diffusion coefficient)를 계산하였 다. 결정화 거동에 따른 영향을 확인하기 위해 TA instruments (미국)사의 Q2000 differential scanning calorimeter(DSC)를 사용하여 분석하였으며, 질소 가스 purging 상태에서 가열 및 냉각속도를 $10^{\circ} \mathrm{C} / \mathrm{min}$ 로 분석하였다.

치수 변화율. 치수 변화율(dimensional change)은 수분 흡 수율의 건조중량 측정 시 시료번호별 시편에 대한 길이 (conditioned length, $\mathrm{CL}$ )를 측정하고, 약 800시간 침지 후 가 습길이(wet length, WL)를 측정하여 식 (2)로 계산하였다.

$$
\frac{(W L-C L)}{C L} \times 100=\text { Dimensional change }(\%)
$$

흡습에 의한 기계적 성질 영향. 흡습에 따른 굴곡강도의 영향은 시편을 $25^{\circ} \mathrm{C}$ 증류수에서 24시간 및 48 시간 동안 침 지한 후 ASTM D790(flexural properties of unreinforced and reinforced plastics and electrical insulating materials)에 따라 온도 $25^{\circ} \mathrm{C}$ 에서 만능 인장시험기(universal testing machine, INSTRON)로 측정하고, 증류수에 침지하지 않은 $25^{\circ} \mathrm{C}$ 에 보관된 시편의 굴곡강도와 비교하였다. 시험조건은 span $50 \mathrm{~mm}$, 하중속도 $1.3 \mathrm{~mm} / \mathrm{min}$ 을 적용하였으며, 굴곡강 도의 측정은 시편의 항복점에서의 하중으로부터 산출하였다. 흡습에 따른 충격강도의 영향은 시편을 $25^{\circ} \mathrm{C}$ 증류수에서 24 시간 및 48시간 동안 침지한 후 ASTM D256(determining the izod pendulum impact resistance of plastics)에 따라 온도 $25{ }^{\circ} \mathrm{C}$ 에서 아이조드(izod)형 충격시험 장비(impact tester, TOYOSEIKI)를 이용하여 측정하고, 증류수에 침지하지 않은 $25^{\circ} \mathrm{C}$ 에 보관된 시편의 충격강도와 비교하였다. 시험조건으로 는 $60 \mathrm{~kg}$ 의 충격하중을 적용하였다.

\section{결과 및 토론}

흡습 특성. 나노복합체의 24 시간 수분 흡수율 시험결과를 Figure 2에 나타내었는데, MMT 함량이 증가할수록 24시간 수분 흡수율, 즉 단위 무게당 수분함량이 선형적으로 감소하 는 경향을 보였다. 이러한 MMT 함량에 따른 수분 흡수율의 감소는 Nylon 6 및 MMT 나노복합체를 연구한 D. P. N. Vlasveld 등과 Nylon 66 나노복합체를 연구한 X. Liu 등이 동일한 경향으로 $\mathrm{MMT}$ 함량이 증가할수록 $\mathrm{MMT}$ 가 나노복 합체 내부 수분 확산에 대한 장애물로서의 영향이 증가함에 따른 현상으로 설명할 수 있다. 즉, 이러한 장애물에 의해 수

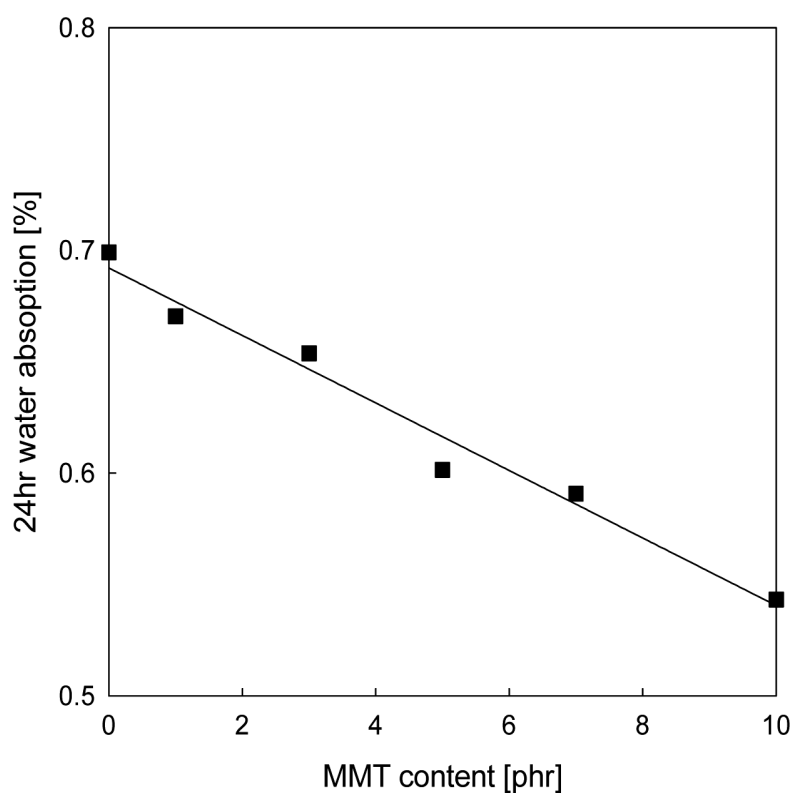

Figure 2. 24 hr-water absorption of nanocomposite with various mixing conditions.

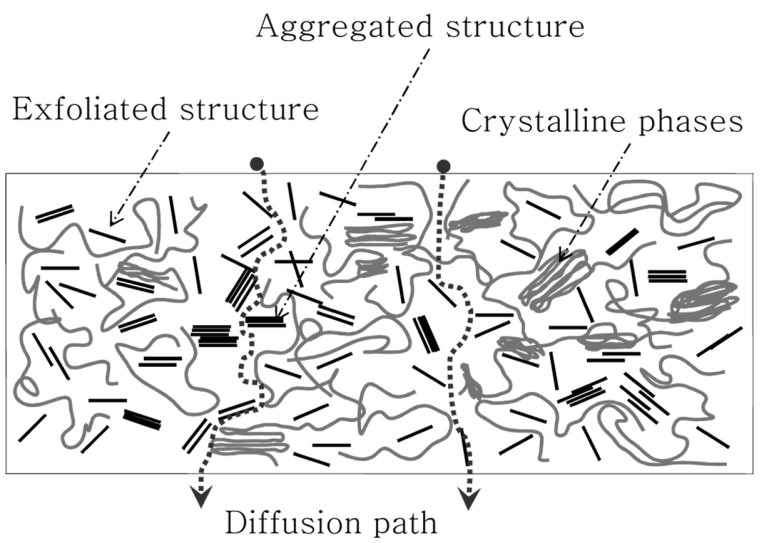

Figure 3. Illustration of the diffusion of water through nanocomposite. $^{26}$

분 확산경로가 증가하게 되고, 수분 흡수율이 감소하게 되는 것으로 판단할 수 있다. 또한 나노복합체 내의 결정부분과 같 은 고정화(immobilized) 영역의 존재도 수분 확산 장애물로 작용하게 되어 수분 흡수율 감소의 영향요소 중 하나인 것으 로 판단된다. ${ }^{721}$ 이와 같이 수분 확산경로가 증가되는 현상은 B. Alexandre 등이 제시한 Figure 3과 같이 나타낼 수 있는 데, 도입된 $\mathrm{MMT}$ 및 폴리아미드의 결정영역에 의한 수분 확 산 간섭이 주요 영향요소로 볼 수 있다. ${ }^{26}$ 결정부분이 수분 확 산에 영향을 미친다는 것은 결정화 영향 인자인 고분자 매 트릭스의 분자량, MMT 도입 함량, 나노복합체 제조공정 등 도 수분 흡수율에 영향을 미치는 것으로 미루어 판단할 수 있다..$^{7-29}$ 


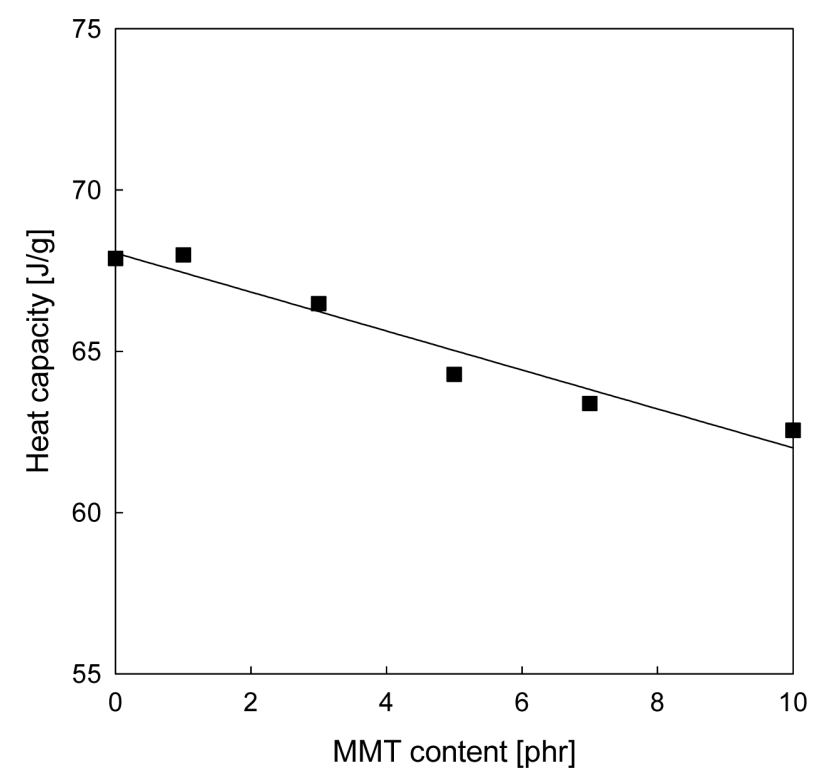

Figure 4. Heat capacity of nanocomposite for crystallization with various mixing conditions.

Figure 4에는 앞서 언급한 결정화 경향을 파악하기 위한 $\mathrm{DSC}$ 분석결과를 나타내었는데, MMT 함량 $1 \mathrm{phr}$ 에서 엔탈 피가 미약하나마 상승하는 경향을 보이고, 그 이상의 $\mathrm{MMT}$ 함량에서는 감소하는 경향으로 나타났다. 이는 $1 \mathrm{phr}$ 의 MMT 함량에서는 MMT가 핵생성 촉진제로서 작용하여 결정화도 의 상승을 가져오나, 그 이상의 함량에서는 핵생성 촉진제로 서의 역할보다 결정 성장 방해 요소로서의 영향이 증가하게 되어 결정화도가 감소되는 현상으로 추정된다. ${ }^{27,28}$ 이러한 결 정화 경향으로부터 Figure 2의 수분 흡수율 감소 경향은 $\mathrm{MMT}$ 함량과 그에 따른 결정화 영향이 복합적으로 영향을 미치는 것으로 판단할 수 있다.

Figure 5에 침지시간 및 $\mathrm{MMT}$ 함량에 따른 수분 흡수율을 나타내었는데, 앞서 제시한 24시간 수분 흡수율에서 MMT 함량 증가에 따라 수분 흡수율이 낮아지는 경향은 침지시간 이 길어지는 경우에도 동일함을 볼 수 있다. 침지시간에 대 해서는 증류수 침지 후 약 200 시간까지는 수분 흡수율이 급 격히 증가하는 경향을 보였다. 이러한 침지시간과 $\mathrm{MMT}$ 의 침지시간에 따른 경향은 D. P. N. Vlasveld 등의 Nylon 6/ MMT 나노복합체 수분 흡수율의 경향과 동일하며, 24 시간 수분 흡수율 결과에서 언급한 바와 같이 MMT의 수분 확산 간섭 영향은 침지시간이 길어지는 경우에도 동일한 것으로 판단할 수 있었다. ${ }^{21}$

일반적으로 $M_{\mathrm{t}} / M_{\max } \cong 0.5$ 까지의 초기 흡수 경향은 시간 $(t)$ 의 제곱근 $\left(t^{1 / 2}\right)$ 에 선형적으로 비례하는 것으로 알려져 있다. 여기서 $M_{t}$ 는 시간 $t$ 에서의 수분 흡수에 따른 중량 증가율이 며, $M_{\max }$ 는 수분 포화상태에서의 수분에 의한 중량 증가율을 나타낸다. ${ }^{21} M_{\max }$ 를 polyamide 66 의 $23{ }^{\circ} \mathrm{C}$ 포화상태로 $8.5 \%$

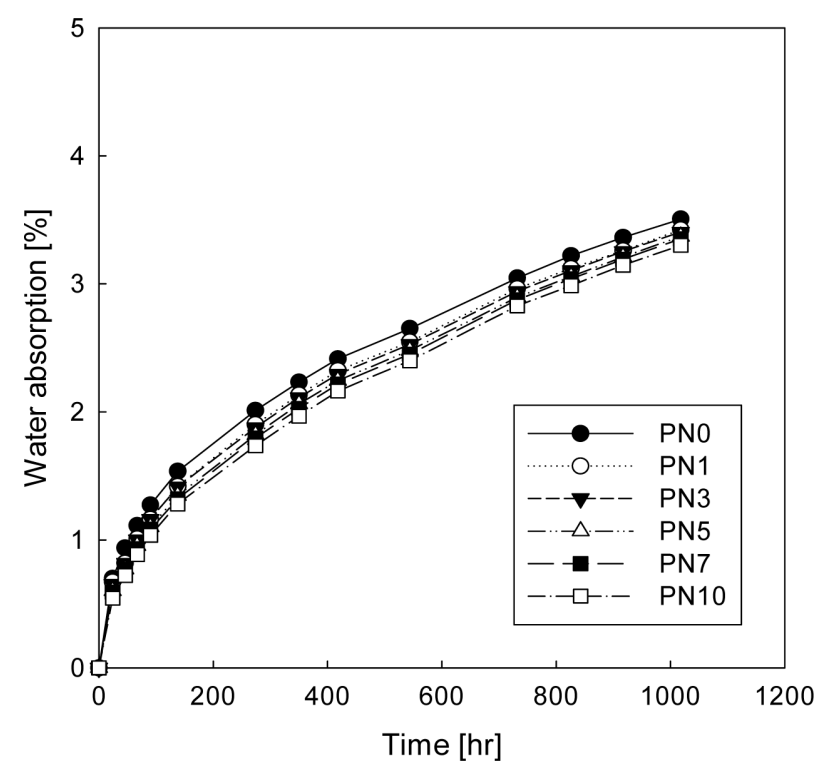

Figure 5. Water absorption of nanocomposite with dipping time.

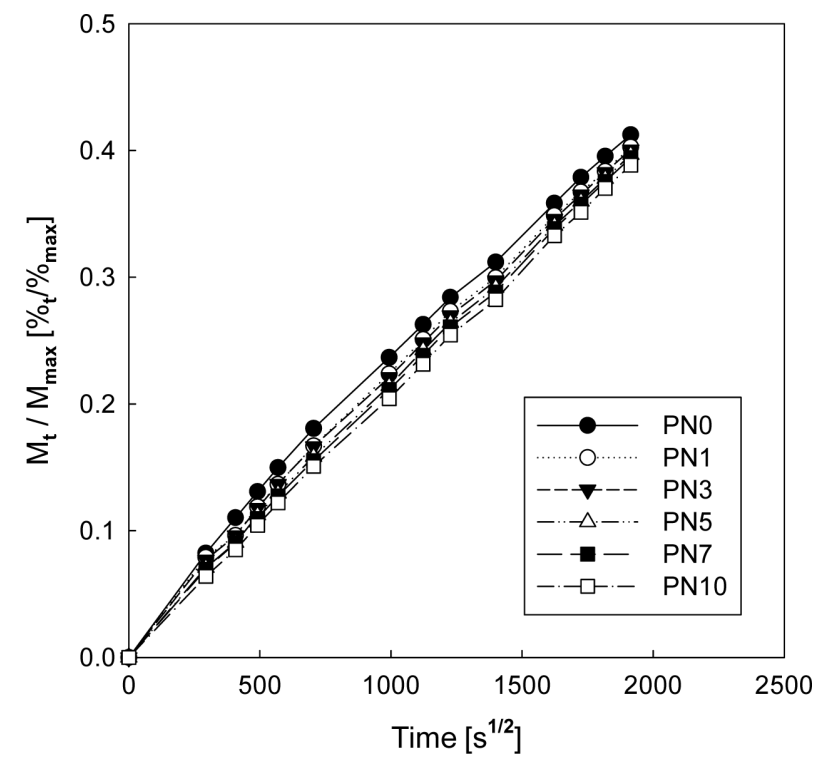

Figure 6. Water absorption of nanocomposite with square root of time.

를 적용하고, ${ }^{23}$ 나노복합체 침지시간에 따른 수분흡수율 Figure 5 의 결과로부터 시간의 제곱근에 따른 $M_{\mathrm{t}} / M_{\max }$ 를 계산하여 Figure 6에 보였다. 도입된 MMT 함량에서 $M_{\mathrm{t}} / M_{\max }$ 가 $t^{1 / 2}$ 에 대해 선형적으로 증가하는 경향을 보임에 따라 polyamide 66/ MMT 나노복합체에서도 수분 흡수경향은 시간의 제곱근에 선형적으로 비례함을 알 수 있었다.

D. P. N. Vlasveld 등은 Fick's second law로부터 다음과 같은 $M_{t} / M_{\max }$ 와 $t^{1 / 2}$ 에 대한 관계식을 제시하였는데, $A_{\text {tot }}$ 는 시 편의 전체 표면적, $V$ 는 시편의 체적, $D$ 는 확산계수를 나타 
낸다. ${ }^{21}$

$$
\frac{M_{\mathrm{t}}}{M_{\max }} \cong \frac{2 A_{\mathrm{tot}}}{V} \sqrt{\frac{D t}{\pi}}
$$

상기 관계식을 $M_{\mathrm{t}} / M_{\max }$ 와 $t^{1 / 2}$ 로 정리하면 그 기울기 $\left(2 A_{\mathrm{tot}} / V\right.$. $\left.(D / \pi)^{1 / 2}\right)$ 로부터 확산계수의 계산이 가능하다. 즉, 앞서 제시한 Figure 6의 결과를 선형분석(linear regression)한 후 각각의 기 울기로부터 확산계수를 계산하여 Figure 7에 나타내었다. 수 분 흡수율과 동일한 경향으로 $\mathrm{MMT}$ 의 함량이 증가할수록 확 산계수가 낮게 나타났으며, 본 연구에서의 최대 확산계수(시 료번호 : PN0)와 최소 확산계수(시료번호 : PN10)의 차이가 PN0 기준으로 약 $17 \%$ 낮아짐을 볼 수 있다. Figure 8 에는 확 산계수로부터 계산된 수분 흡수율 $\left(M_{\mathrm{t}} / M_{\max }\right)$ 과 시험결과를 $M_{\mathrm{t}}$ ' $M_{\max } 0.5$ 까지의 범위에서 비교하여 나타내 보였는데 상기 식 에 의해 예측된 수분 흡수율 경향이 시험결과에 근접함에 따 라 본 연구 나노복합체에 대해 침지시간에 따른 수분 흡수율 의 예측이 가능하였다. 또한 Figure 8 에서 예측된 수분 흡수 율을 0.5 인 지점까지 연장하여 나타낸 결과, 확산계수가 최대 인 $\mathrm{PN} 0$ 과 최소인 $\mathrm{PN} 10$ 에 대해 수분 흡수율이 0.5 까지 도달 하는 시간을 비교해 보면 PN10 나노복합체가 PN0 기준 도 달 시간이 약 $21 \%$ 증가함을 볼 수 있다. 이러한 결과는 나노 복합체를 물에 침지할 경우의 수분 흡습 결과로써 일반 대기 중의 습기(습도) 노출에 대한 나노복합체의 흡습 방지 효과 는 더욱더 지대할 것으로 예상할 수 있다. 즉, $\mathrm{MMT}$ 도입에 따른 수분 흡수율의 감소는 나노복합체를 상용화함에 있어 수분에 대한 내환경성이 요구되는 용도의 적용에 큰 강점으 로 작용할 것으로 판단된다. 특히 제품 생산 후 일반 대기 중

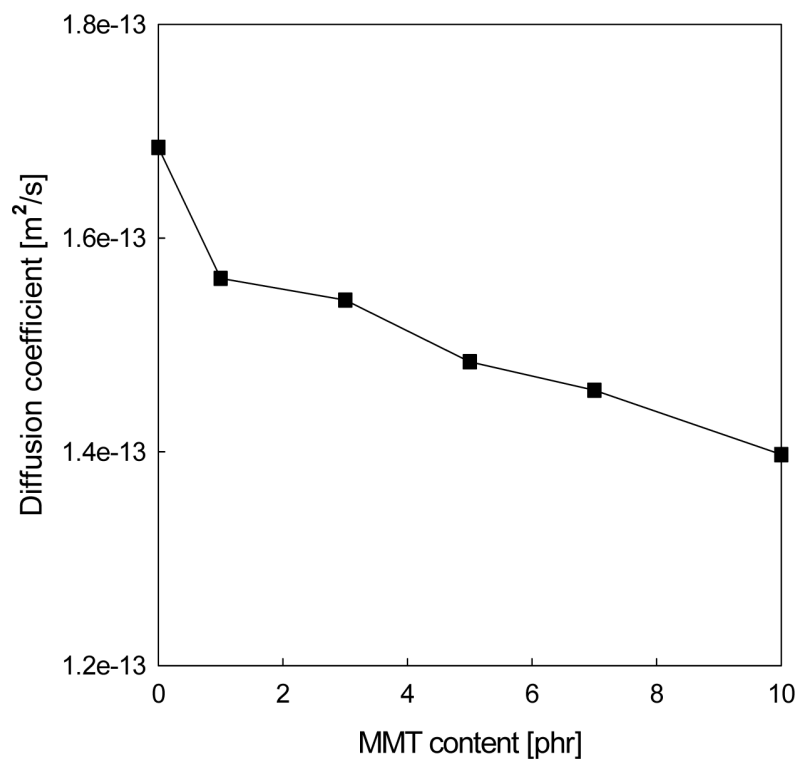

Figure 7. Diffusion coefficient of nanocomposite with various mixing conditions.
에 장기간 저장이 요구되는 탄약과 같은 제품의 경우, 수분 흡습에 따른 영항을 최소화시킬 수 있을 것으로 판단된다.

치수 변화율. 고분자에 $\mathrm{MMT}$ 함량을 증가시킴에 따른 나 노복합체의 수분 흡수율이 감소하는 경향은 시편의 치수변화 에 직접적인 영향을 미치는 요소 중 하나인 것으로 보고된 바 있다. ${ }^{7}$ Figure 9에 Nylon 66 나노복합체에 대해 MMT 함 량에 따른 시편의 치수 변화율을 보였는데, 본 연구에서도 MMT 함량이 증가할수록 치수 변화율이 감소하는 동일한 경 향을 나타내었다. 이는 $\mathrm{MMT}$ 함량 증가에 따라 수분 흡수율

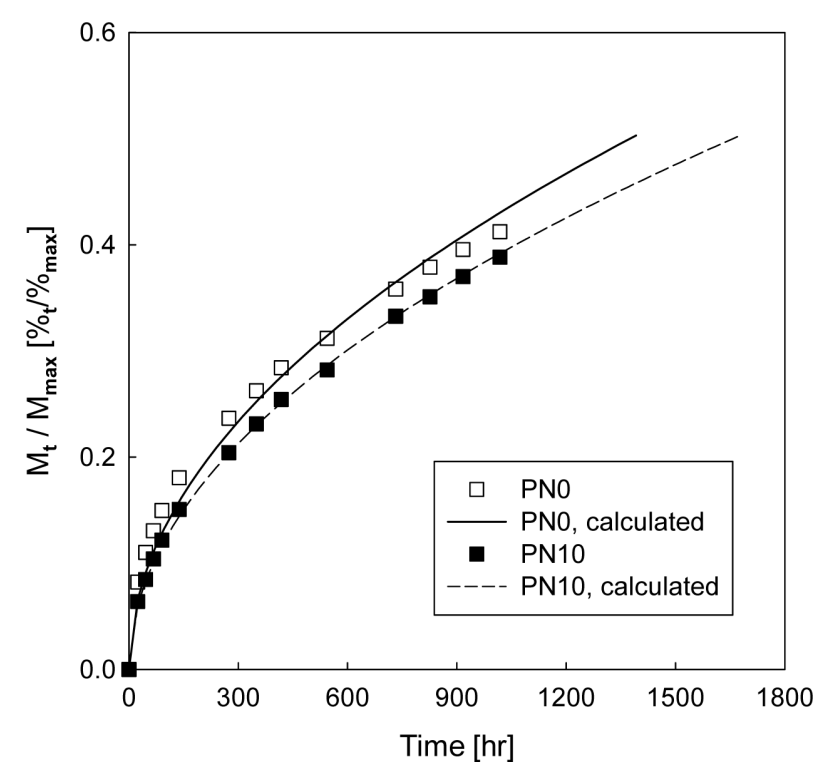

Figure 8. Calculated water absorption $\left(M_{\mathrm{t}} / M_{\max }\right)$ of nanocomposite.

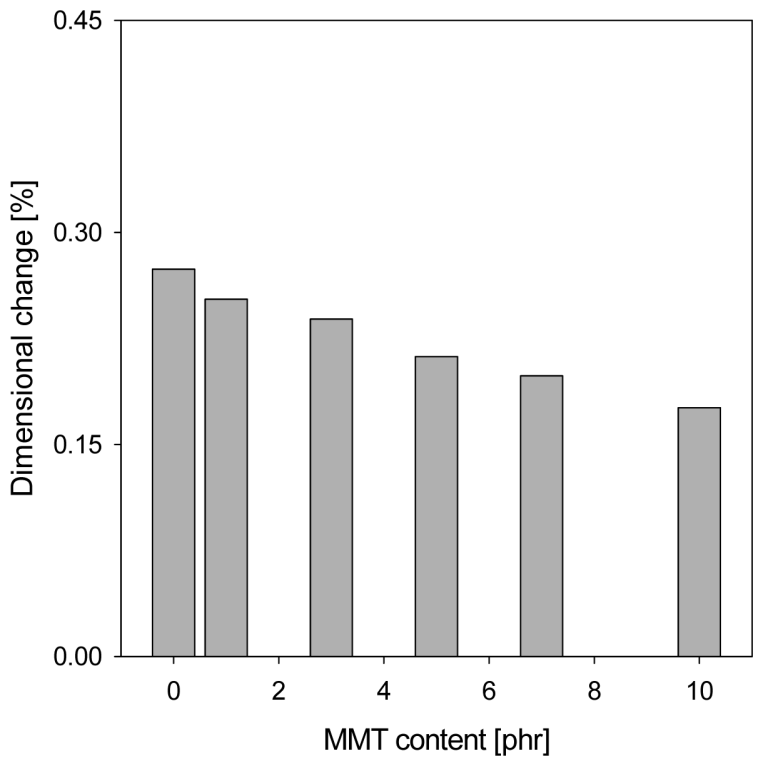

Figure 9. Dimensional change of nanocomposite with various mixing conditions. 


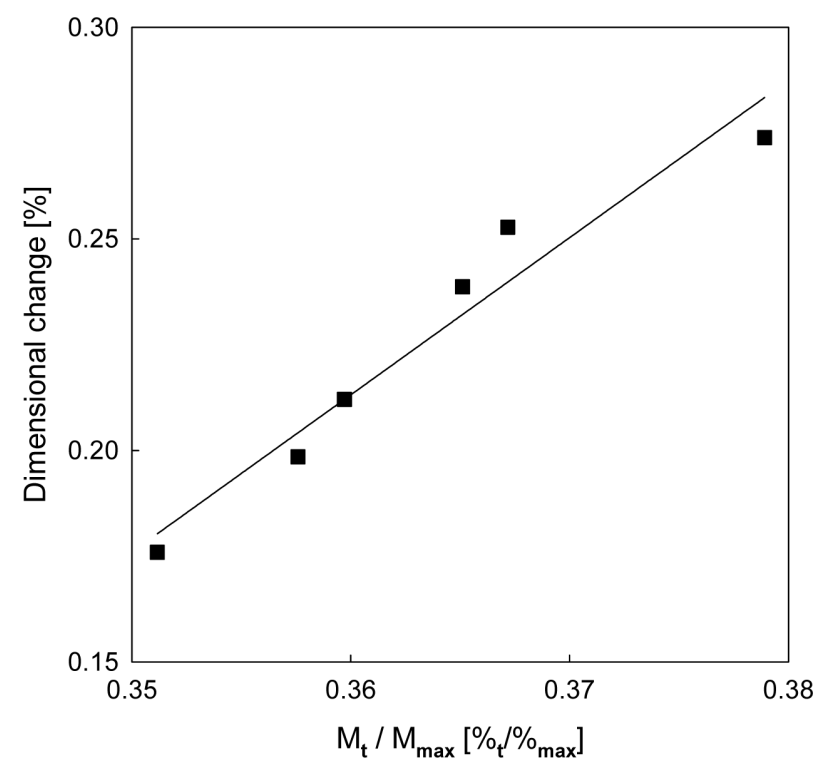

Figure 10. Dependence of dimensional change on water absorption.

이 감소하는 결과와 동일한 경향이며, Figure 10 에서 수분 흡 수율과 치수 변화율이 선형적으로 비례관계에 있음을 확인할 수 있었다. 즉, Nylon 66에 MMT를 도입함에 따라 수분 확 산계수의 저하로 수분 흡수율이 감소함과 동시에 나노복합체 의 치수 안정성(dimensional stability)을 향상시킬 수 있는 것 으로 판단할 수 있었다. 이는 탄약과 같이 일반 대기 중에 장 기 보관한 후에도 초기 생산 치수규격의 유지가 요구되는 특 수한 용도를 포함한 나노복합체의 상업적 응용에 있어 중요 한 강점 중 하나로 작용할 것으로 판단된다. ${ }^{7}$

흡습에 의한 기계적 성질 영향. MMT 함량별로 Nylon 66 나노복합체 시편을 증류수에 각각 24시간, 48시간 침지한 후 의 굴곡강도와 동일 환경에서 증류수에 침지하지 않은 시편 의 굴곡강도를 Figure 11 에 비교하여 나타내었다. 먼저, 증류 수에 침지하지 않은 시편의 굴곡강도는 $\mathrm{MMT}$ 함량이 증가 함에 따라 증가하는 경향을 보였다. 이는 MMT 도입에 의한 강도보강 효과 및 분산상태가 양호한 MMT와 고분자 매트 릭스와의 접촉면적 증가로 굴곡강도가 향상되는 것으로 판단 할 수 있다. ${ }^{8} 24$ 시간 침지 후에는 굴곡강도가 $\mathrm{MMT}$ 함량 $5 \mathrm{phr}$ 기준 약 $13 \%$ 감소되고, 48 시간 침지 후에는 약 $19 \%$ 감 소하는 것으로 나타났다. Figure 12에는 흡수에 따른 굴곡탄 성률을 나타내었는데 침지시간 및 MMT 함량에 따른 경향 이 굴곡강도 경향과 동일하게 나타났으며, 24시간 침지 후 굴 곡탄성률이 MMT 함량 $5 \mathrm{phr}$ 기준 약 $17 \%$ 감소되고, 48 시 간 침지 후에는 약 $29 \%$ 감소하는 경향을 보였다. 폴리아미 드계 고분자는 친수성이 강한 amide group에 의해 흡습이 용 이하고, 흡습된 수분이 가소제로서 작용하여 다른 고분자에 비해 기계적 성질의 변화가 큰 것으로 알려져 있다. ${ }^{19-21}$ 상기 와 같은 Nylon 66 나노복합체의 흡수에 따른 굴곡강도 및 굴

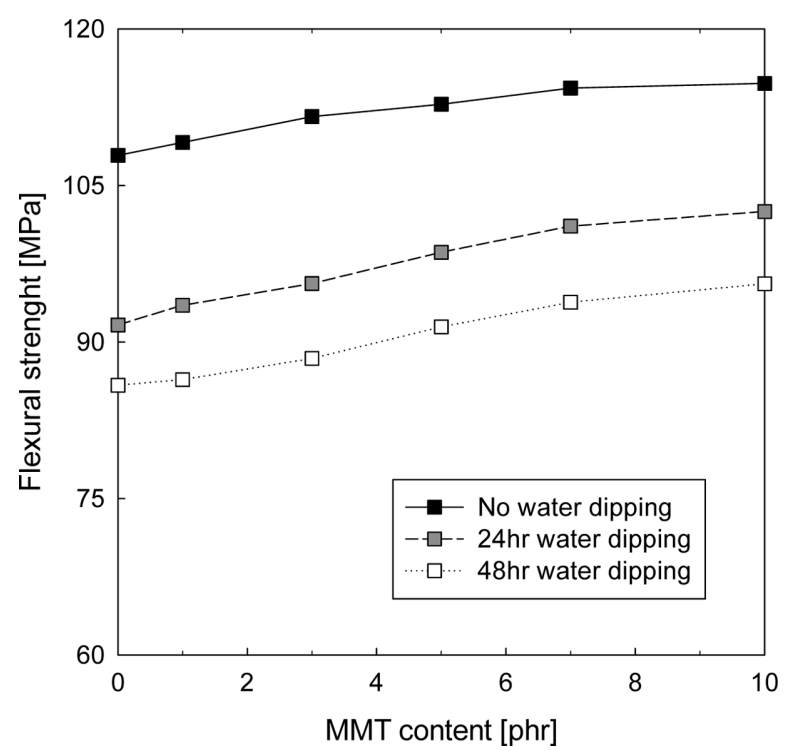

Figure 11. Flexural strength of nanocomposite with various mixing conditions and water absorption.

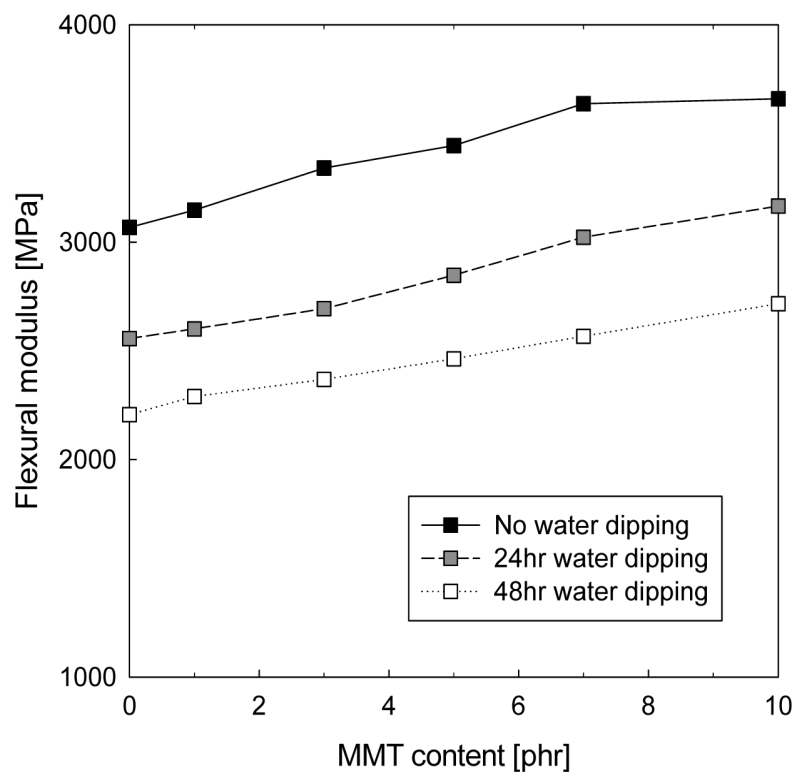

Figure 12. Flexural modulus of nanocomposite with various mixing conditions and water absorption.

곡탄성률의 감소는 고분자 매트릭스의 가소성의 증가에 따른 현상으로 설명이 가능하며, 이러한 고분자 매트릭스의 특성 이 나노복합체의 굴곡응력에 대한 특성에 직접적으로 영향을 미침을 알 수 있다. 이러한 흡습에 따른 굴곡응력에 대한 경 향으로부터 $\mathrm{MMT}$ 함량이 증가할수록 굴곡강도가 증가하고 수분 흡수율은 감소하며, 수분 흡수율이 감소할수록 굴곡강 도가 증가되는 경향을 알 수 있다. 즉, Nylon 66 나노복합체 에서 $\mathrm{MMT}$ 의 도입으로 굴곡강도가 증가하는 현상은 고분자 
매트릭스에 균일하게 분산된 $\mathrm{MMT}$ 가 고분자 매트릭스와의 접촉 면적이 증가하여 강도 보강 효과를 부여함과 동시에 $\mathrm{MMT}$ 의 함량이 증가할수록 나노복합체의 수분 흡수율이 감 소함에 따라 강도 저하 영향이 감소하게 되는 현상이 동시에 영향을 미친 것으로 판단할 수 있다. 이러한 결과로부터 굴 곡 응력에 대한 저항력이 요구되는 재료를 설계함에 있어서 수분 흡수율에 대한 관리규격이 포함되어야 할 것으로 판단 된다. 흡수에 따른 Nylon 66 나노복합체의 굴곡강도 영향에 대한 연구결과를 찾아보기 어려우나, D. P. N. Vlasveld 등 의 Nylon 6과 MMT의 나노복합체 연구 결과에서 나노복합 체의 수분함량이 증가할수록 인장응력에 대한 영탄성률 (Young's modulus)이 감소함을 확인할 수 있으며, 이 또한 수 분 흡수로 amide-water 수소결합이 형성되어 영탄성률이 감 소한 현상으로 수분 흡수에 따른 연성파괴 거동(ductile fracture behaviour)이 영향을 미친 것으로 설명하고 있다. ${ }^{21}$ 이 러한 결과로부터 폴리아미드계 나노복합체는 흡습에 따라 인 장 및 굴곡응력에 의한 강도가 저하되는 것으로 판단할 수 있다. 폴리아미드계 복합체의 수분 흡수에 따른 굴곡강도 영 향에 대해서는 polyamide 6과 PTFE(polytetra-fluoroethylene), polyamide 66과 PTFE의 복합체에 대한 R. G. Zhao 등의 연 구결과에서 시편을 24 시간 침지 후 굴곡강도가 약 $20 \%$ 감소 하는 것으로 보고하고 있으며, 이러한 경향은 수분 분자가 고 분자 사슬로 침투되어 그 조밀성에 영향을 주기 때문, 즉 가 소성을 부여함에 따른 것으로 설명하고 있으므로 폴리아미드 계 고분자의 흡습은 고분자 매트릭스에 직접적으로 영향을 주어 굴곡강도를 감소시키는 것으로 판단할 수 있다. ${ }^{22}$

MMT 함량별로 나노복합체 시편을 증류수에 각각 24시간, 48시간 침지한 후의 충격강도와 동일 환경에서 증류수에 침 지하지 않은 시편의 충격강도를 Figure 13에 비교하여 나타 내었다. 증류수에 침지하지 않은 시편의 충격강도는 $\mathrm{MMT}$ 함량 증가로 나노복합체가 취성(brittle) 특성을 지님에 따라 감소하는 경향을 보였다. 흡습에 따른 강도변화는 앞서 제시 한 굴곡강도와는 상반된 경향으로 수분 흡수 후에도 충격강 도의 변화가 없음을 볼 수 있다. 일반적으로 폴리아미드계 고 분자는 흡습에 따라 연성파괴 거동의 경향을 보여 충격강도 에 영향을 미칠 것으로 예상할 수 있으나, ${ }^{21}$ 본 연구의 충격 강도 시험조건에서는 순간적인 충격응력에 대해 수분 흡수에 따른 가소성의 증가가 영향을 미치지 않는 것으로 판단할 수 있으며, Nylon 66/MMT 나노복합체가 일반 대기에 노출될 경우 흡습에 따른 충격강도의 영향은 미약할 것으로 추정된 다. Polyamide 6과 PTFE, polyamide 66과 PTFE 복합체의 흡습에 따른 기계적 성질에 대한 R. G. Zhao 등의 연구결과 에서도 건조된 시편과 증류수에 24 시간 침지 후 시편의 충격 강도가 차이가 없음을 보이고 있으므로 폴리아미드계 고분자 의 흡습은 충격강도에 대한 영향이 크지 않은 것으로 추정된 다. ${ }^{22}$

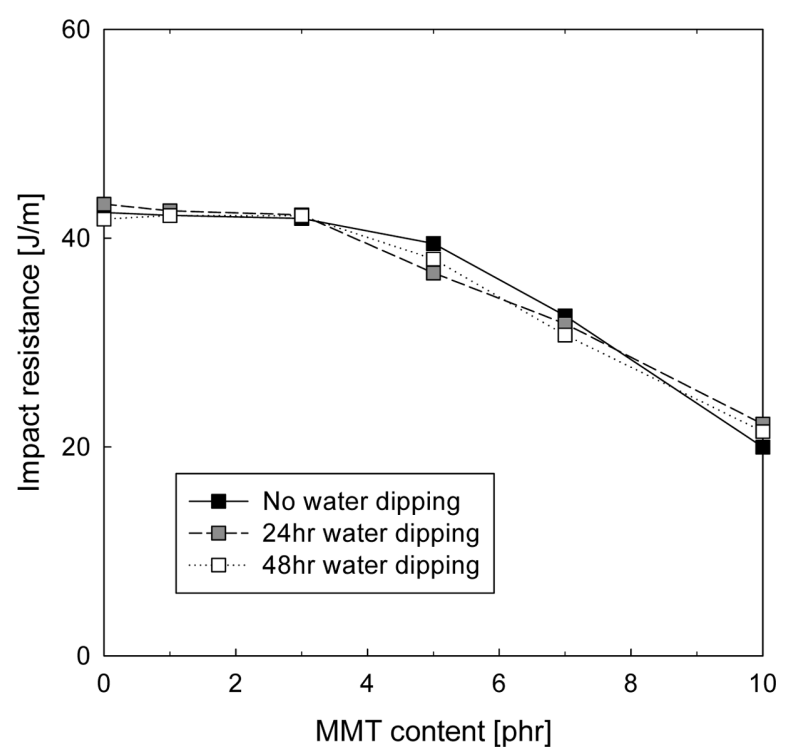

Figure 13. Impact resistance of nanocomposite with various mixing conditions and water absorption.

\section{결 론}

용융 삽입법으로 pilot scale의 이축 압출기로 제조된 Nylon 66/MMT 나노복합체에 대한 흡습 특성, 흡습에 따른 치수변 화 및 기계적 성질 영향을 연구하였다.

수분 흡수율은 MMT가 수분 확산의 장애물로 작용하여 $\mathrm{MMT}$ 함량이 증가함에 따라 수분 흡수율이 감소하였다. 침 지시간에 따른 수분 흡수 경향은 최대 흡수율에 대한 일정 침지시간에서의 흡수율 $\left(M_{\mathrm{t}} / M_{\max }\right)$ 이 시간의 제곱근 $\left(t^{1 / 2}\right)$ 에 대해 선형적으로 증가하는 경향을 확인할 수 있었으며, 이러한 시 험결과로부터 MMT 함량별 나노복합체에 대한 확산계수를 계산한 결과 $\mathrm{MMT}$ 함량이 증가할수록 확산계수가 감소하였 고 확산계수가 최대 $17 \%$ 까지 낮아짐을 볼 수 있었다. 확산 계수로부터 계산된 수분 흡수율 $\left(M_{\mathrm{t}} / M_{\max }\right)$ 경향이 시험결과와 일치하여 수분 흡수율의 예측이 가능하였으며, 수분 흡수율 이 0.5 까지 도달하는 기간이 MMT 함량에 따라 최대 $21 \%$ 증가하는 것으로 예상할 수 있었다. 즉, $\mathrm{MMT}$ 도입에 따른 나노복합체의 흡습방지 효과를 확인할 수 있었으며, 이러한 흡습방지 효과는 치수 변화율에도 직접적으로 영향을 미치게 되어 치수 안정성을 향상시킴을 확인할 수 있었다.

흡습에 따른 기계적 성질은 수분 흡수 시간이 길어질수록, 즉 수분 흡수율이 증가할수록 수분이 가소제로 작용하여 굴 곡응력에 대한 강도 및 탄성률이 감소하는 경향을 보였다. 이 러한 결과로부터 나노복합체는 MMT 도입에 의한 강도 향 상효과와 흡습방지에 의한 강도 저하 방지효과가 굴곡강도 향상에 동시에 영향을 미치는 것으로 판단할 수 있었다. 반 면, 본 시험조건에서의 충격강도는 수분 흡습에 의한 강도변 
화가 없으므로 흡습에 의한 영향이 미약한 것으로 판단할 수 있었다.

\section{참 고 문 헌}

1. O. Monticelli, Z. Musina, F. Ghigliotti, S. Russo, and V. Causin, e-Polymers, No.124 (2007).

2. A. Usuki, Y. Kojima, M. Kawasumi, A. Okada, Y. Fukushima, T. Kurauchi, and O. Kamigaito, J. Mater. Res., 8, 179 (1993).

3. S. H. Wu, F. Y. Wang, C.-C. M. Ma, W. C. Chang, C.-T. Kuo, H.C. Kuan, and W.-J. Chen, Mater. Lett., 49, 327 (2001).

4. P. Uribe-Arocha, C. Mehler, J. E. Puskas, and V. Altstadt, Polymer, 44, 2441 (2003).

5. T. Kashiwagi, R. H. Harris, Jr., X. Zhang, R. M. Briber, B. H. Cipriano, S. R. Raghavan, W. H. Awad, and J. R. Shields, Polymer, 45, 881 (2004).

6. B. Mu, Q. Wang, T. Wang, H. Wang, and L. Jian, Polym. Eng. Sci., 48, 203 (2008).

7. X. Liu and Q. Wu, Macromol. Mater. Eng., 287, 180 (2002).

8. F. Chavarria, and D. R. Paul, Polymer, 45, 8501 (2004).

9. X. H. Liu and Q. J. Wu, Macromol. Mater. Eng., 287, 180 (2002).

10. M. Mehrabzadeh and M. R. Kamal, Polym. Eng. Sci., 44, 1152 (2004).

11. B. Han, G. D. Ji, S. S. Wu, and J. Shen, Eur. Polym. J., 39, 1641 (2003).

12. L. Shen, I. Y. Phang, L. Chen, T. X. Liu, and K. Y. Zeng, Polymer, 45, 3341 (2004).

13. D. P. N. Vlasveld, S. G. Vaidya, H. E. N. Bersee, and S. J. Picken, Polymer, 46, 3452 (2005).

14. P. M. Gyoo, S. Venkataramani, and S. C. Kim, J. Appl. Polym. Sci., 101, 1711 (2006).
15. Y. L. Lu, Y. Zhang, G. B. Zhang, M. S. Yang, S. K. Yan, and D. Y. Shen, Polymer, 45, 8999 (2004).

16. Z.-Z. Yu, M. S. Yang, Q. X. Zhang, C. G. Zhao, and Y.-W. Mai, J. Polym. Sci. Part B: Polym. Phys., 41, 1234 (2003).

17. X. H. Liu, Q. J. Wu, and L. A. Berglund, Polymer, 43, 4967 (2002).

18. Y. L. Lu, G. B. Zhang, M. Feng, Y. Zhang, M. S. Yang, and D. Y. Shen, J. Polym. Sci. Part B: Polym. Phys., 41, 2313 (2003).

19. S. J. Lee, Polym. Sci. Techn., 1, 134 (1990).

20. M. T. Hahn, R. W. Hertzberg, J. A. Manson, and L. H. Sperling, Polymer, 27, 1885 (1986).

21. D. P. N. Vlasveld, J. Groenewold, H. E. N. Bersee, and S. J. Picken, Polymer, 46, 12567 (2005).

22. T. D. Fornes, P. J. Yoon, H. Keskkula, and D. R. Paul, Polymer, 42, 9929 (2001).

23. Z. Z. Yu, C. Yan, M. Yang, and Y. W. Mai, Polym. Int., 53, 1093 (2004).

24. S. S. Lee, M. Park, S. H. Lim, J. K. Kim, and J. T. Hwang, Polym. Sci. Techn., 18, 8 (2007).

25. J. H. Choi, J. KIMST, 9, 88 (2006).

26. B. Alexandre, D. Langevin, P. Mederic, T. Aubry, H. Couderc, Q. T. Nguyen, A. Saiter, and S. Marais, J. Membrane Sci., 328, 186 (2009).

27. Q. X. Zhang, Z. Z. Yu, M. Yang, J. Ma, and Y. W. Mai, J. Polym. Sci. Part B: Polym. Phys., 41, 2861 (2003).

28. D. S. Homminga, B. Goderis, Vincent B. G. Mathot, and G. Groeninckx, Polymer, 47, 1630 (2006).

29. B. Lin, A. Thümen, H.-P. Heim, G. Scheel, and U. Sundararaj, Polym. Eng. Sci., 49, 824 (2009). 